DOI:10.17951/h.2021.55.1.7-18

\begin{tabular}{lcc}
\hline \multicolumn{3}{c}{ A N N A L E S } \\
UNIVERSITATIS MARIAE CURIE-SKŁODOWSKA \\
LUBLIN - POLONIA \\
SOL. LV, 1 & SECTIOH \\
\hline
\end{tabular}

\author{
AGATA ANTCZAK-STĘPNIAK \\ agata.antczak@uni.lodz.pl \\ University of Łódź. Faculty of Economics and Sociology \\ 3/5 POW St., 90-255 Łódź, Poland \\ ORCID ID: https://orcid.org/0000-0002-5858-2774
}

\title{
Conditions for the Growth of Developers' Activity on the Example of Poland and France
}

Keywords: developers' activity; comparative analysis; nationwide factors

JEL: R31; R38; K25

How to quote this paper: Antczak-Stępniak, A. (2021). Conditions for the Growth of Developers' Activity on the Example of Poland and France. Annales Universitatis Mariae Curie-Skłodowska, sectio $H$-Oeconomia, Vol. 55, No. 1.

\footnotetext{
Abstract

Theoretical background: Developers' activity shows strong spatial diversification. These differences can be observed both between individual countries and within them - between cities. This means that developers' activity is affected by a number of diverse factors of a national and local nature, which is also confirmed by the literature on the subject. This is a particularly important conclusion for developers operating at an international level. They have to make decisions in which country, and then in which city, development projects will bring the best results.

Purpose of the article: The aim of this article is to identify nationwide barriers to the growth of developers' activity, especially those that are evident in periods of recession, as well as solutions that should be taken to facilitate the functioning of such entities in Poland.

Research methods: To achieve this aim, the desk research method and comparative analysis were used. A country which, apart from Poland, has been analyzed is France.

Main findings: The conducted research showed that the main nationwide barriers to the growth of developers' activity are insufficient purchasing power of the population resulting from the lower wealth of the Polish society, different regulations regarding the protection of buyers of developer dwellings, a smaller level of government support for both the demand and supply side of developers' activity. Especially, the
} 
last barrier should be taken under consideration. In the near future, due to the cyclical nature of the real estate market, a drop in demand for dwellings should be expected. Therefore, aid instruments for developers should be introduced to avoid a wave of bankruptcy. They could consist of both training enabling retraining of activities into commercial or increasing the involvement of these entities in the implementation of housing for rent for people with lower incomes.

\section{Introduction}

At present, development activity plays a significant role in shaping the supply of new dwellings in Poland. It is, however, strongly spatially diversified. These differences are visible between cities as well as between Poland and other countries. This means that there are a number of national and local determinants that cause this diversity. It may also result from a different understanding of the developer definition in various countries. There is no doubt, however, that in some countries development activity in the housing market is thriving more than in others. Therefore, it is worth considering these determinants to understand the reasons for the better functioning of developers abroad in order to be able to take measures to facilitate this activity in Poland, especially in situations of recession.

Thus, the aim of this article is to identify national barriers to the growth of development activity, especially those that are visible in periods of recession, as well as solutions that should be taken to facilitate the functioning of such entities in Poland. To achieve the indicated goal, the desk research method and comparative analysis of conditions occurring in Poland and France were used.

\section{Literature review}

Decent housing conditions are essential in the life of every person, necessary for meeting basic human needs (Mulroy \& Ewalt, 1996, p. 245; Kędzierska, 2009, p. 147; McCray \& Day, 1977, pp. 244-254). Unfortunately, in many countries around the world, including Poland, we observe a deficit of dwellings, especially those affordable (see: Monkkonen, 2013, pp. 1-21; Napiórkowska-Baryła, Witkowska-Dąbrowska, \& Manuel de Jesus, 2016, pp. 103-114; Granath Hansson, 2018, pp. 93-99; Afrane, Bin Bujang, Liman, \& Kasim, 2016, pp. 139-147; Khater, Kiefer, \& Yanamandra, 2020, pp. 1-11). For this reason, it is important to provide a supply of housing for people with different financial possibilities (a housing ladder allows a release of dwellings previously used by more affluent people who move to new and larger flats and houses). In Poland, developers have been creating the largest share in supply of dwellings for several years. Their role in the Polish housing market has been gradually increasing since the 1990s. Also abroad, the importance of developers in the development of housing construction leaves no doubt, although their activity varies (cf. Lai \& Wang, 1999, pp. 143-159; Sanfelici \& Halbert, 2016, pp. 1-21). 
Developers' activity is usually understood as economic activity aiming at such transformation of real estate that causes its value increase (Śmietana \& Zagórska, 2009 , pp. 160-161). This activity may vary in detail between individual countries. It can be partly due to the diversity of definitions of the developer (see: D'Arcy \& Keogh, 2002, p. 19; Davis, 2007, p. 14; Schoonbrodt, 1987, p. 52; Wendling et al., 2008, p. 198; Kucharska-Stasiak, 2016, p. 348). The basic difference that results from the consideration of the above-mentioned researchers' works concerns the fact that this activity not always must be performed in order to achieve a profit. The developer can therefore also operate in the non-profit formula. Due to the fact that only for-profit developers operate in Poland (see: Antczak-Stępniak, 2017, pp. 74-83), further considerations will focus on these types of entities.

Spatial diversification of developers' activity (between countries, cities, districts) may also result from a large number of factors affecting it, both national (macro-factors) and local (meso-factors) ones (for more, see: Antczak-Stępniak, 2015a, pp. 42-54; Antczak-Stępniak, 2015b, pp. 73-84). This is also confirmed by the review of the Polish literature (Gostkowska-Drzewicka, 2010, p. 50; Kucharska-Stasiak, 2010, p. 105; Kokot, 2012, pp. 53-69; Grodzka, 2002, pp. 28-32) as well as the foreign literature (Smersh, Smith, \& Schwartz Jr., 2003, pp. 61-75; Sirya, 2017). Figure 1 illustrates holistic classification of mentioned factors.

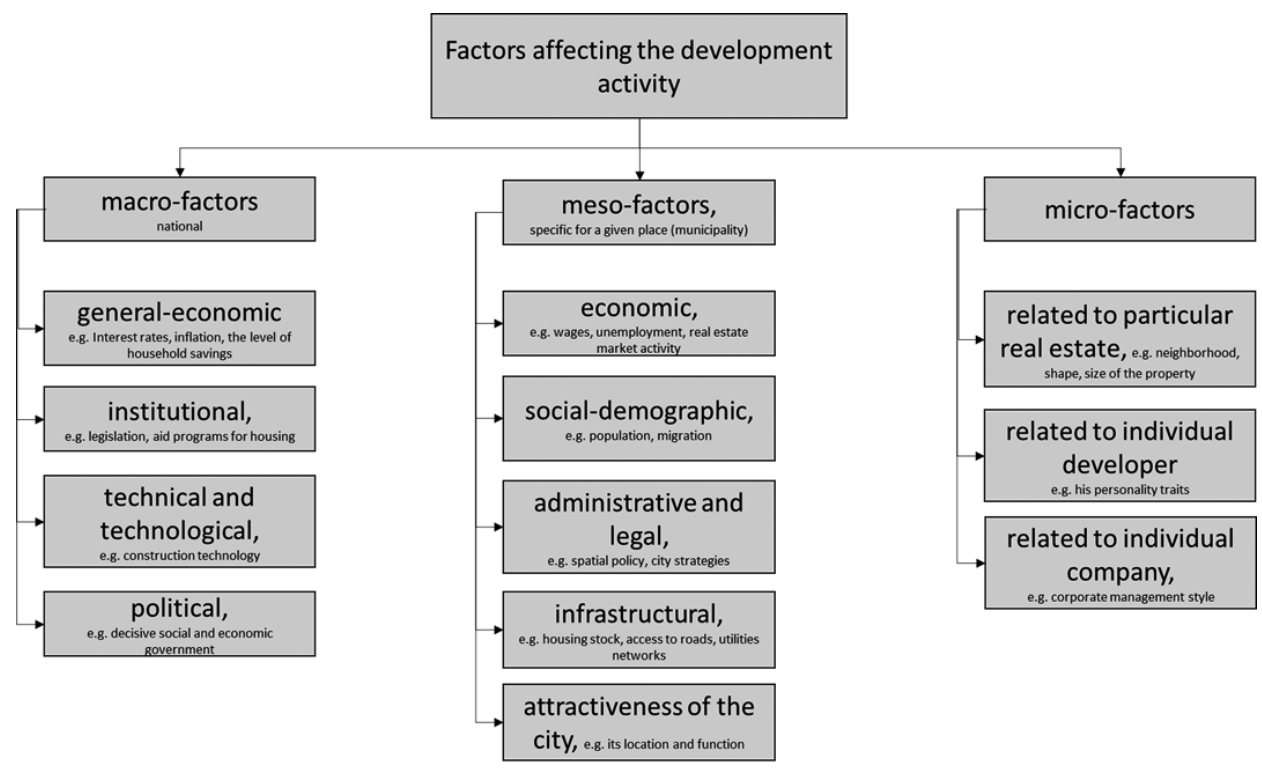

Figure 1. Factors affecting the growth of development activity 
Considering the fact that housing market is local (Kucharska-Stasiak, 2016, pp. 5869), it is obvious that local factors specific to given cities and micro-factors will result in diversification of development activity. However, nationwide factors (macro-factors) that differ between countries will also affect the volume of development activity in question. Therefore, a comparative analysis of these conditions abroad may reveal some barriers to the functioning of developers in Poland, and thus show solutions that could help streamline the discussed activity. Today, development activity in Poland is growing, due to the high demand generated by people from the demographic boom of the 1980s. However, this demand will someday decrease as a result of the cyclicality of the real estate market (see: Mueller \& Pevnev, 1997; Glaeser, 2017, pp. 114-151; Żelazowski, 2017, pp. 5-14). It will be important then to have the appropriate institutional and economic environment that will allow developers to continue their activity.

\section{Research methods}

The desk research method is based on the use of existing data: statistics and public summaries, official documents, data and information available online, etc. Such data primarily helps to obtain a broad context of knowledge on a given topic, but also allows the researcher to collect and analyze data for a specific topic (Bednarowska, 2015, pp. 18-26). Comparative analysis allows us to collate and analyze similarities and differences between two or more objects. Thanks to this, attempts can be made to identify the cause-and-effect relationships of the studied phenomena (Bukhari, 2011).

France was selected for the comparative analysis due to a matured developers' market with solutions and tools created during many years of evolution. Although it is a country that still faces some housing problems (La construction de logements...), a more efficiently working institutional environment allows to limit these problems quite quickly.

A variety of macro-factors influence developers' activity, but only quantifiable ones (for which it was possible to obtain comparable data) and the most important changes in the institutional environment will be included in further analysis. Systematization of factors for the growth of developers' activity selected for the study is presented in Table 1.

Table 1. Factors considered in the study

\begin{tabular}{|l|l|}
\hline \multicolumn{2}{|c|}{ Macro-factors } \\
\hline \multirow{3}{*}{ General-economic } & - inflation rate \\
& - growth of GDP per capita \\
& - interest rates \\
& - gross domestic savings in GDP \\
\hline Institutional & - legal regulations directly related to the development activity \\
& - housing support programs \\
\hline
\end{tabular}

Source: Author's own elaboration. 
Other information concerning, among others, political, technical and technological factors (macro-factors), were not comparable between France and Poland.

The basic source of data on general-economic factors for Poland and France was the World Bank, European Central Bank and National Bank of Poland, while information on institutional factors was collected from government websites regarding housing support programs and laws regulating developers' activity. In the case of France, a report describing the legal system of the real estate market was also used (see: Glock, pp. 44-52). General-economic data cover the years 1995-2018, with the exception of interest rates (from 2008).

To compare the scale of development activity between the analyzed countries, data on the number of dwellings (developers' and total) started in the years 19952018, converted per 1,000 inhabitants, were compiled (in Poland, these data are only available from 2005). The data were obtained from the Local Data Bank of the CSO, the French statistical office INSEE and SDES.

\section{Research results}

Due to the fact that Poland and France differ in terms of population, the difference in the number of dwellings that are built in these countries is obvious. Therefore, in order to ensure comparability of data, they were converted per 1,000 inhabitants (Figure 2).

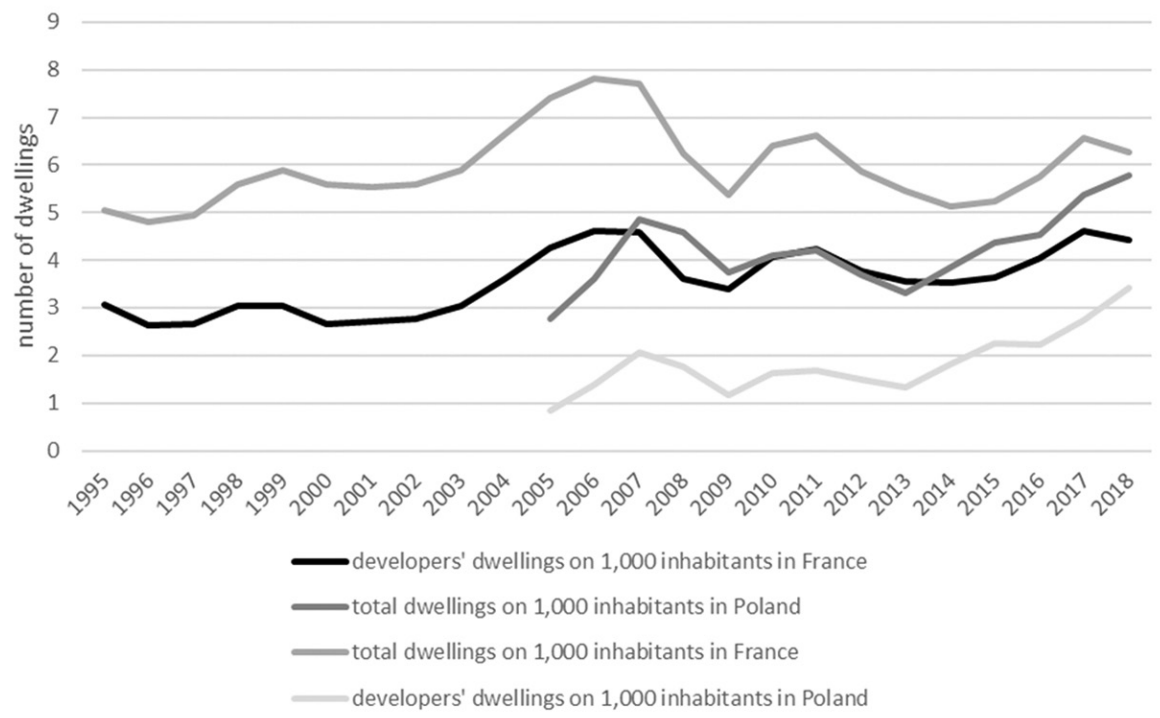

Figure 2. Number of total and developer's started dwellings converted to 1,000 inhabitants in Poland and France in 1995-2018 
Despite the conversion of the total number of dwellings and developers' dwellings started into 1,000 inhabitants, in France these indices assume higher values. This proves that the growth of development activity in this country is more dynamic. Nevertheless, it is noteworthy that in recent years this indicator for Poland has increased sharply, while in France in 2017-2018 a downward trend was recorded. Therefore, it is worth considering what the differences between these countries result from in order to better recognize the conditions for the growth of development activity in Poland.

\section{General-economic factors}

The diversification of developers' activity between Poland and France may result from all macro-factors presented in Section 2 (Literature review). Figure 3 presents a synthetic summary of the most important general economic parameters characterizing both countries.

a)

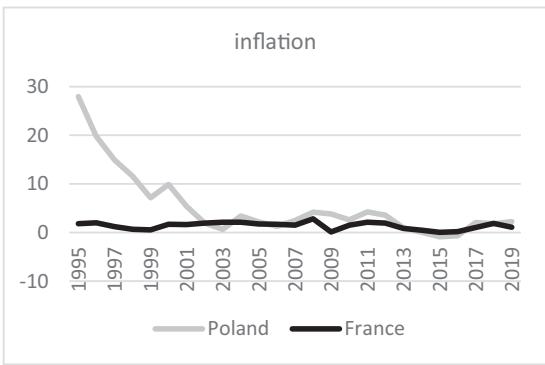

c)

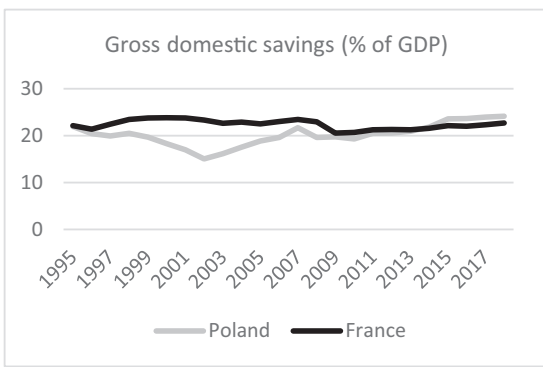

b)

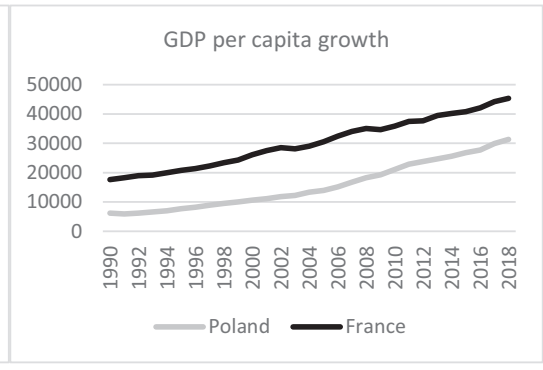

d)

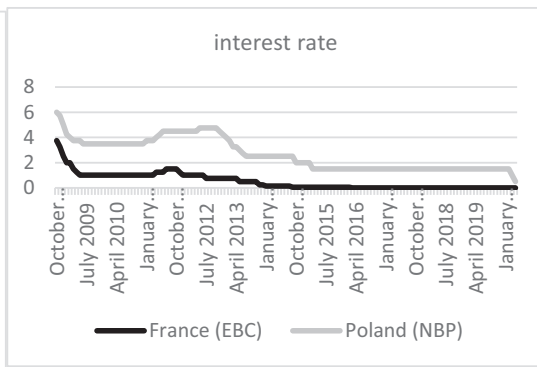

Figure 3. Comparative analysis of selected general-economic factors in the compared countries: a) inflation rate, b) growth of GDP per capita, c) gross domestic savings in GDP (\%), d) interest rates*

Source: Author's own elaboration based on (World Bank data, ECB and NBP).

*The reference rate in Poland means the profitability of 7-day treasury bills, while in France the rates published by the European Central Bank were applied - the interest rate on the main refinancing operations (MRO), which provide the bulk of liquidity to the banking system. 
As regards the general-economic factors (Figure 3), two issues are particularly worth noting, namely the growth of GDP per capita and interest rates. The pace of GDP per capita growth is similar in both countries. However, the level of this indicator looks completely different. There is no doubt that French society is more wealthy than Polish one. Thus, the purchasing power of the French people may be higher, although it also depends on the level of prices of goods and services, including residential real estate. Low interest rates encourage borrowing in both countries. They make interest rates on loans also beneficial for both mortgage and consumer loans. In France, a zero interest rate results in savings (not necessarily in the form of deposits) and securing them against impairment, among others, by acquiring real estate. In Poland, they are also at a low (in April 2020 - 0.5\%), though positive, level, and high demand caused by a large number of buyers from the 1980s (demographic boom) encourages developers to be more active.

The share of gross domestic savings in GDP is also an interesting variable. ${ }^{1}$ Over the years, France had better results, but recently the trend has reversed. This means that savings of Polish households as well as of the private and public sectors are growing, which may increase the propensity to invest, also in real estate. The level of inflation in both countries is similar. Unfortunately, in recent years, a slight increase in prices, including prices of production factors, has been noticeable in Poland. This results in an increase in the cost of investment implementation, and thus an increase in prices of final products of development activity, i.e. flats and houses. Thus, although the compared countries differ in terms of general economic conditions, in particular the level of wealth of the society, one can say that in both of them the conditions for the growth of development activity are good.

\section{Institutional factors}

With regard to developers' activity, many different types of legal regulations are important. These include regulations concerning ownership rights, transfer of rights to the buyer, the possibility of establishing mortgage security on real estate, etc. In many countries, this activity is regulated by separate regulations (e.g. in Poland - Ustawa z dnia 16 września 2011 r...). In France, there are also similar provisions, although they do not result from a separate act. Provisions related to developers' activity can be found in the Civil Code (Civil Code, Article 1601) and in the Building and Housing Code (Code de la construction et de l'habitation, Article L261). It should be emphasized that they have been in existence for about 50 years, and thus there are less frequent abuses in relation to buyers. In France, most regulations are not mandatory, with the exception of the protected sector, i.e. dwellings under construction (Glock, p. 44).

\footnotetext{
1 According to the World Bank, "gross domestic savings are calculated as GDP less final consumption expenditure (total consumption)" (World Bank).
} 
The legal regulations applicable in Poland are quite different from the French solutions. Basic similarities and differences in this regard are presented in Table 2.

Table 2. Similarities and differences in legal regulations related to the residential developers' activity

\begin{tabular}{|l|l|l|}
\hline \multicolumn{1}{|c|}{ Specification } & \multicolumn{1}{|c|}{ Poland } & \multicolumn{1}{c|}{ France } \\
\hline $\begin{array}{l}\text { Developer/preliminary } \\
\text { agreement }\end{array}$ & Obligatory, notarial deed & $\begin{array}{l}\text { Obligatory, the form of a notarial deed is not } \\
\text { required }\end{array}$ \\
\hline $\begin{array}{l}\text { The moment of signing } \\
\text { the developer/preliminary } \\
\text { agreement }\end{array}$ & $\begin{array}{l}\text { The earliest after obtaining } \\
\text { a building permit, preferably } \\
\text { after the commencement of } \\
\text { construction works }\end{array}$ & $\begin{array}{l}\text { Even before the developer acquires rights to the } \\
\text { land }\end{array}$ \\
\hline Form of the sales contract & Notarial deed & Notarial deed \\
\hline $\begin{array}{l}\text { The moment of signing } \\
\text { the sales contract }\end{array}$ & After obtaining a use permit & It may be signed during the construction works \\
\hline Payment schedule & Min. 4 stages & $\begin{array}{l}35 \% \text { - foundations } \\
70 \% \text { raw open state } \\
95 \% \text { - completed construction } \\
100 \% \text { - handing over the keys }\end{array}$ \\
\hline Place of depositing funds & Escrow accounts & $\begin{array}{l}\text { It is allowed to deposit funds directly to the } \\
\text { developer's bank account }\end{array}$ \\
\hline $\begin{array}{l}\text { Forms of purchaser } \\
\text { protection }\end{array}$ & $\begin{array}{l}\text { Escrow accounts (four types of } \\
\text { accounts differing in the scope } \\
\text { of protection of buyers' funds) }\end{array}$ & $\begin{array}{l}\text { Guarantees for the completion of construction } \\
\text { works or refunds in the event of termination of } \\
\text { the contract due to the incompletion. They can } \\
\text { also be provided by the bank or insurance compa- } \\
\text { nies. The entry must be in the sales contract. }\end{array}$ \\
\hline
\end{tabular}

Source: Author's own elaboration based on (Glock, pp. 44-52; Ustawa z dnia 16 września 2011 r...).

Although it may seem that the protection of purchasers' rights in France is weaker, the long period (regulations introduced in the 1970s) of the validity of these regulations has helped to develop the skill of fair play in development companies. Therefore, it does not discourage the buyers that the preliminary contract is signed in the ordinary written form or that they buy the proverbial "hole in the ground". The more that they are protected by a guarantee of completion or refund. Assuming an identical situation in both countries, namely that the developer declares bankruptcy during the implementation of the project in Poland, the buyer whose funds are probably protected by the open escrow account can count on the return of funds engaged in the investment (however, these funds may be reimbursed over a longer period of time) or on the completion of the investment by the special purpose vehicle established by the buyers, or by another developer (Ustawa z dnia 28 lutego 2003 r...). In France, in turn, the guarantee of reimbursement assures that the buyer will receive the money paid for developer and in case of guarantee of completion he will receive money needed to complete the construction works (more: Glock, pp. 48-49). In fact, Polish law also gives the option of using guarantee, but in practice it is a dead instrument.

The Polish "Development Act" is currently being amended. Its basic assumption is to increase the protection of buyers by introducing an additional safeguard in the form of the Development Guarantee Fund (Archiwalny wykaz prac...). 
In the area of state support for the development of housing, there are also quite significant differences between the studied countries. In Poland, until 2018, there was only support of the demand side, i.e. the "Mieszkanie dla Młodych" program, thanks to which people wishing to purchase a dwelling from a developer could receive support in the form of co-financing for their own contribution. Unfortunately, there were some limitations to the possibility of using this program, i.e. the age of the beneficiary, the size and price of the dwelling, the need to credit at least $50 \%$ of the purchase of real estate, etc. (Ustawa z dnia 27 września 2013 r...). Currently, there is no support for people who want to buy a dwelling. In France, however, a lot of actions are taken to support both the demand and the supply side.

The forms of support for developers' activity in the housing market by state authorities are presented in Table 3.

Table 3. Comparative analysis of the identified forms of support for developers' activity

\begin{tabular}{|c|c|c|}
\hline Specification & Poland & France \\
\hline Demand side & $\begin{array}{l}\text { - there is no support for } \\
\text { buyers }^{2}\end{array}$ & $\begin{array}{l}\text { - free-interest loans } \\
\text { - PINEL's scheme } \\
\text { - } 80,000 \text { houses for young people, also students, during } 5 \\
\text { years }\end{array}$ \\
\hline Supply side & $\begin{array}{l}\text { - increasing the availability } \\
\text { of agricultural land within } \\
\text { the administrative borders } \\
\text { of cities, as well as unused } \\
\text { post-industrial, post-military } \\
\text { and post-industrial areas } \\
\text { - the decision on determining } \\
\text { the location of a residential } \\
\text { investment should be issued } \\
\text { within } 60 \text { days, not a few } \\
\text { months } \\
\text { - the provisions of the deci- } \\
\text { sions may be different from the } \\
\text { provisions of local plans }\end{array}$ & $\begin{array}{l}\text { - facilitating the transformation of offices into a flat } \\
\text { - limiting the number of parking spaces, if the investment has } \\
\text { good access to public transport } \\
\text { - encouraging construction between existing buildings, } \\
\text { - shortening the time of appealing } \\
\text { - enabling the purchase of public lands at lower costs pro- } \\
\text { vided that part of the built housing is transferred to the social } \\
\text { housing stock } \\
\text { - limitation of the number of technical standards, for residen- } \\
\text { tial buildings } \\
\text { - tax credits on profits from land sales ( } 100 \% \text { for the sale } \\
\text { of land for the construction of social housing, } 85 \% \text { for } \\
\text { intermediate housing and } 70 \% \text { for others, including property } \\
\text { development) }\end{array}$ \\
\hline
\end{tabular}

Source: Author's own elaboration based on (Ustawa z dnia 5 lipca 2018 r...; The government's housing strategy...; La construction de logements...).

As can be seen in Table 3, the number of solutions facilitating developers' activity both on the demand and on the supply side is greater in France. This is the country's response to the housing shortage that has occurred in this country as a result of the

2 There are few programs to support people who want to rent a dwelling in new housing (e.g. "Mieszkanie Plus", "Mieszkanie na Start"), but according to Bank Gospodarstwa Krajowego (BGK), their efficiency is low for now (https://www.bgk.pl/files/public/Pliki/bip/Mieszkanie_na_start/Lista_ Gmin/2021_01_04_wykaz_gmin.pdf).

3 Few plots of land meet the criteria set out in the Act, especially since municipalities adopt local urban standards that further tighten these criteria. In addition, few investments obtain decisions on the location of a residential investment due to, among others, residents' protests. 
global crisis. Therefore, the government has taken measures to create a supply shock in areas where the housing problems are large and indeed since 2016 there has been an improvement in the number of dwellings being started (La construction de logements...). In Poland, the housing deficit is also a problem. The question, therefore, is why the support of housing development is at such a low level. Perhaps it stems from the fact that in the next 5 years the population is expected to decline by nearly 178,000, and in the 10-year period - by 530,000 (Prognoza ludności rezydującej...).

\section{Conclusions}

To sum up, it should be clearly stated that spatial diversification of developers' activity is visible. Based on the analyzes carried out, the following barriers to the growth of development activity in Poland can be identified:

- insufficient purchasing power of the population resulting from the lower level of wealth of Polish society,

- different regulations regarding the protection of buyers of developer dwellings,

- insufficient level of government support for both the demand and supply side of development activity.

The wealth of society is difficult to influence in a short period of time, but the other two barriers are possible to overcome. As regards changes in regulations concerning the purchase of developer dwellings, actions have already been taken, which should increase public confidence in this activity. However, there remains the issue of financial support for both the demand and supply side of development activity. Currently, there is quite a lot of people who want to buy or rent a dwelling in Poland, but in the near future, due to the cyclical nature of the real estate market, a drop in demand for dwellings should be expected. Therefore, aid instruments for developers should be introduced to avoid a wave of bankruptcies. These measures could consist of training that would enable transitioning of those activities into commercial ones or increasing the involvement of these entities in the implementation of housing for rent for people with lower incomes. The "Lex Developer" Act was to favor this latter category of activities, but ultimately a small group of entities decided to carry out such activities. Therefore, these provisions need to be improved. Currently, there is a bill regulating the "Lokal za Grunt" program, which assumes the purchase of municipal land by developers in return for the transfer of some developer dwellings to the municipal housing stock. Such solutions are already used abroad, e.g. in Italy, Great Britain or Spain.

It should be emphasized, however, that the constantly changing economic and institutional environment requires research in this area to be continued. 


\section{References}

Afrane, E., Bin Bujang, A.A., Liman, H.S., \& Kasim, I. (2016). Major Factors Causing Housing Deficit in Ghana. Developing Country Studies, 6(2), 139-147.

Archiwalny wykaz prac legislacyjnych i programowych Rady Ministrów z okresu 4 grudnia 2015 r. - 21 listopada 2019 r. Retrieved from https://bip.kprm.gov.pl/kpr/form/r807189517,Projekt-ustawy-o-zmianie-ustawy-o-ochronie-praw-nabywcy-lokalu-mieszkalnego-lub-.html

Antczak-Stępniak, A. (2015a). Residential Development Activity in the Polish Legal Setting. Real Estate Management and Valuation, 23(1), 42-54. doi:10.1515/remav-2015-0004

Antczak-Stępniak, A. (2015b). Local Factors Influencing the Increase in Development Activity in Selected Cities of Poland. Real Estate Management and Valuation, 23(3), 73-84. doi:10.1515/remav-2015-0027

Antczak-Stępniak, A. (2017). Possibilities for the Growth of Social Housing with the Participation of Developers in Poland. Real Estate Management and Valuation, 25(1), 74-83. doi:10.1515/remav-2017-0004

Bank Danych Lokalnych Głównego Urzędu Statystycznego. Retrieved from https://bdl.stat.gov.pl/BDL/start

Bank Gospodarstwa Krajowego. Retrieved from https://www.bgk.pl/files/public/Pliki/bip/Mieszkanie_na start/Lista_Gmin/2021_01_04_wykaz_gmin.pdf

Bednarowska, $\bar{Z}$. (2015). Desk research - wykorzystanie potencjału danych zastanych w prowadzeniu badań marketingowych i badań społecznych. Marketing i Rynek, 7/2015, 18-26.

Bukhari, S.A.H. (2011). What Is Comparative Study. Retrieved from https://ssrn.com/abstract=1962328; doi:10.2139/ssrn.1962328

D’Arcy, É., \& Keogh, G. (2002). The Market Context of Property Development Activity. In S. Guy, \& J. Henneberry (Eds.), Development and Developers: Perspectives of Property (pp. 19-34). Oxford: Blackwell Science Ltd.

Davis, T. (2007). The Real Estate Developer's Handbook: How to Set Up, Operate, and Manage a Financially Successful Real Estate Development. Ocala: Atlantic Publishing Group Inc.

European Central Bank. Retrieved from https://www.ecb.europa.eu/stats/policy_and_exchange_rates/key_ ecb_interest_rates $/ \mathrm{html} /$ index.en.html

Glaeser, E.L. (2017). Real Estate Bubbles and Urban Development. Asian Development Review, 34(2), 114-151.doi:10.1162/adev_a_00097

Glock, S. Real Property Law Project. France. Retrieved from https://www.eui.eu/Documents/DepartmentsCentres/Law/ResearchTeaching/ResearchThemes/EuropeanPrivateLaw/RealPropertyProject/France.PDF

Gostkowska-Drzewicka, M. (2010). Próba określenia wpływu czynników makroekonomicznych na rozwój mieszkaniowego rynku deweloperskiego w Trójmieście na tle Polski w latach 1995-2007. Barometr Regionalny, 1(19), 45-59.

Granath Hansson, A. (2018). Combatting the Housing Shortage Through Institutional Reform: The Parallel Cases of Germany and Sweden. ZFV - Zeitschrift für Geodäsie, Geoinformation und Landmanagement, 143(2), 93-99. doi:10.12902/zfv-0197-2018

Grodzka, I. (2002). Czynniki sukcesu dewelopera. Nieruchomości, 8(48).

Institut national de la statistique et des études économiques (INSEE). Retrieved from https://www.insee.fr/fr/ statistiques/1892117?sommaire $=1912926$

Kędzierska, M. (2009). Kształtowanie polityki mieszkaniowej w warunkach gospodarki rynkowej. Equilibrium, 1(2), 147-157.

Khater, S., Kiefer, L., \& Yanamandra, V. (2020). The Housing Supply Shortage: State of the States. Economic $\&$ Housing Research Insight, Freddie Mac.

Kokot, S. (2012). Analiza zmian uwarunkowań podejmowania inwestycji deweloperskich w wybranych miastach Polski. Studia i Materiały Towarzystwa Naukowego Nieruchomości, 20(1), 53-69.

Kucharska-Stasiak, E. (2010). Uwarunkowania rozwoju działalności deweloperskiej w Polsce. Badania Naukowe, 25(2), 105-114.

Kucharska-Stasiak, E. (2016). Ekonomiczny wymiar nieruchomości. Warszawa: PWN. 
La construction de logements. Retrieved from https://www.gouvernement.fr/action/la-construction-de-logements

Lai, N., \& Wang, K. (1999). Land-Supply Restrictions, Developer Strategies and Housing Policies: The Case in Hong Kong. International Real Estate Review, 2(1), 143-159.

McCray, J.W., \& Day, S.S. (1977). Housing values, aspirations, and satisfactions as indicators of housing needs. Home Economics Research Journal, 5(4), 244-254. doi:10.1177/1077727X7700500404

Monkkonen, P. (2013). Housing Deficits as a Frame for Housing Policy: Demographic Change, Economic Crisis and Household Formation in Indonesia. International Journal of Housing Policy, 13(3), 1-21. doi:10.1080/14616718.2013.793518

Mueller, G., \& Pevnev, A. (1997). An Analysis of Rental Growth Rates During Different Points in the Real Estate Market Cycle. Presented at the American Real Estate Society Meetings. Sarasota, FL.

Mulroy, E.A., \& Ewalt, P.L. (1996). Affordable Housing: A Basic Need and a Social Issue. Social Work, 41(3), 245-249.

National Bank of Poland. Retrieved from https://www.nbp.pl/home.aspx?f=/dzienne/stopy_archiwum.htm

Napiórkowska-Baryła, A., Witkowska-Dąbrowska, M., \& Manuel de Jesus, I. (2016). Sytuacja mieszkaniowa w Polsce w latach 2007-2013 w kontekście zmian demograficznych. Humanities and Social Sciences, 21(23/3), 103-113.

Prognoza ludności rezydujacej dla Polski na lata 2015-2050. Retrieved from http://stat.gov.pl/obszary-tematyczne/ludnosc/prognoza-ludnosci/prognoza-ludnosci-rezydujacej-dla-polski-na-lata-2015-2050,8,1.html

Sanfelici, D., \& Halbert, L. (2016). Financial Markets, Developers and the Geographies of Housing in Brazil: A Supply-Side Account. Urban Studies, 53(7), 1465-1485. doi:10.2307/26151124

Schoonbrodt, R. (1987). Essai sur la destruction des villes et des campagnes. Liège: Pierre Mandaga.

Service de la donnée et des études statistiques (SDES). Retrieved from https://www.statistiques.developpement-durable.gouv.fr/construction-de-logements-resultats-fin-janvier-2020-france-entiere?rubriqu$\mathrm{e}=53 \&$ dossier $=1047$

Sirya, L.T. (2017). Factors Influencing Real Estate Companies Investment Decisions in Commercial Properties in Nairobi County, Kenya. A research project submitted in partial fulfilment of the requirement for the award of the degree of master of science in finance, School of Business University of Nairobi.

Smersh, G.T., Smith, M.T., \& Schwartz, Jr. A.L. (2003). Factors Affecting Residential Property Development Patterns. JRER, 25(1), 61-75.

Śmietana, K., \& Zagórska, E. (2009). Deweloper jako profesjonalny uczestnik rynku nieruchomości. In H. Henzel (Ed.), Strategie inwestowania na rynku nieruchomości (pp. 149-166). Katowice: Wydawnictwo Akademii Ekonomicznej.

The government's housing strategy. Retrieved from https://www.gouvernement.fr/en/the-government-s-housing-strategy

Ustawa z dnia 28 lutego 2003 r. Prawo upadłościowe, Dz.U. 2020 poz. 1228 (The Act of 28 February 2003 Bankruptcy Law, Journal of Laws of 2020, item 1228).

Ustawa z dnia 16 września 2011 r. o ochronie praw nabywcy lokalu mieszkalnego lub domu jednorodzinnego, Dz.U. $2011 \mathrm{nr} 232$ poz. 1377 (The Act of 16 September 2011 on the protection of the rights of the purchaser of a flat or a single-family home, Journal of Laws of 2011, No. 232, item 1377).

Ustawa z dnia 27 września 2013 r. o pomocy państwa w nabyciu pierwszego mieszkania przez młodych ludzi, Dz.U. 2013 poz. 1304 (The Act of 27 September 2013 on the state aid in purchasing first flat by young people, Journal of Laws of 2013, item 1304).

Ustawa z dnia 5 lipca 2018 r. o ułatwieniach w przygotowaniu i realizacji inwestycji mieszkaniowych i inwestycji towarzyszących, Dz.U. 2018 poz. 1496 (The Act of 5 July 2018 on the facilitation of the preparation and implementation of housing investments and accompanying investments, Journal of Laws of 2018, item 1496).

Wendling, P. et al. (2008). Immobilier Strasbourg. Agglomération et environs. Paris: Petit Futé.

World Bank. Retrieved from https://data.worldbank.org/country/

Żelazowski, K. (2017). Housing Market Cycles in the Context of Business Cycles. Real Estate Management and Valuation, 25(3), 5-14. doi:10.1515/remav-2017-0017 